The 2 nd Conf. of SSFOP "Future of Ornamental Plants in Egypt and Arab World", Cairo,

Egypt, 21/2/2016

Scientific J. Flowers \& Ornamental Plants

www.ssfop.com/journal

ISSN: 2356-7864

\title{
EFFECT OF NPK AND GIBBERELLIC ACID ON GROWTH AND QUALITY OF CYCAS REVOLUTA"THUNB."
}

\author{
Boshra A. El-Sayed*, T.M. Noor El-Deen*, Lobna M. Abdel-Galeil** and M.A. El-Ashwah* \\ * Ornamental Plants and Landscape Gardening Res. Dept., Hort. Res. Inst., ARC, Giza, Egypt. \\ ** Central Lab. for Res. \& Date Palm Develop., Hort. Res. Inst., ARC, Giza, Egypt.
}

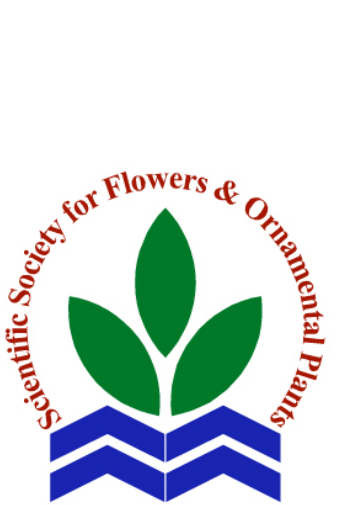

Scientific J. Flowers \& Ornamental Plants, 3(1):87-94 (2016).

Received: $10 / 1 / 2016$

Revised by: Prof. Dr. E.S. Nofal, Kafr El-Sheikh Univ.

Prof. Dr. A.Z. Sarhan, Cairo Univ.

ABSTRACT: A series of pot experiments was consummated in open field at the nursery of Hort. Res. Inst., Giza, Egypt during 2014 and 2015 seasons to find out the effect of NPK at $2 \mathrm{~g} /$ pot, gibberellic acid at 500, and $1000 \mathrm{ppm}$ concentrations (as a foliar spray 6 times with one month interval) and their interaction on vegetative and root growth and chemical composition of 1-year-old Cycas revoluta, Thunb. plants grown in 20-cm-diameter plastic pots filled with about $2.5 \mathrm{~kg}$ of a mixture of washed sand, and compost $(3: 1, \mathrm{v} / \mathrm{v})$.

The obtained results indicated that all fertilization treatments significantly improved all vegetative and root growth traits of plants used in this study compared to control, especially the combined \& treatment between NPK at $2 \mathrm{~g} /$ pot and gibberellic acid at $1000 \mathrm{ppm}$ as well as, the leaves content of chlorophylls a and $b$, carotenoids and total carbohydrates, $\mathrm{N}, \mathrm{P}$ and $\mathrm{K} \%$ which were significantly increased in response to the different treatments employed in the present study, with the superiority of the combination between NPK at $2 \mathrm{~g} /$ pot and $\mathrm{GA}_{3}$ at $1000 \mathrm{ppm}$. The least record, on the other hand, was found due to NPK at $5 \mathrm{~g} / \mathrm{l}$ alone. A similar trend was also obtained concerning the contents of chlorophyll $\mathrm{a}, \mathrm{b}$, carotenoids, $\mathrm{N}, \mathrm{P}$ and $\mathrm{K} \%$.

Hence, in order to get the best vegetative and root growth it is recommended to treat the plants with NPK at $2 \mathrm{~g} /$ pot per $20-\mathrm{cm}-$ diameter plastic pot plus spraying the foliage to run-off with $1000 \mathrm{ppm}$ of $\mathrm{GA}_{3}$ solution 4 times with 1 month interval.

Key words: Cycas revoluta Thunb.; gibberellic acid; NPK; vegetative and root growth; chemical composition.

\section{INTRODUCTION}

Cycas revoluta, Thunb. (Fam. Cycadaceae), Sage palm is a graceful palmlike tree or shrub, becoming 6-10 feet high, with the trunk simple or branching. Leaves long and recurved (2-7 feet), pinnae numerous, subopposite curved downward, narrow, stiff, acute, terminating in a spinelike tip, dark shining green. This is the most common cycas in conservatories, Javanese origin, it is usually found in all of the better parks and gardens, it is suitable as a center about which to arrange other ornamental shrubs, this species is of slow growth. (Bailey, 1950).

Many workers proved that the good nutrition with any type of fertilizers usually improves growth and quality of various plants. This truth was emphasized by AbdelFattah et al. (2009) who revealed that the combination of $\mathrm{Fe}+\mathrm{Zn}+\mathrm{Mn}$ at $240+120+$ $120 \mathrm{ppm}$ and active dry yeast at $8 \mathrm{~g} / \mathrm{l}$ significantly enhanced vegetative and root growth of Schefflera transplants, as well as leaf content of chlorophylls $a$ and $b$, carotenoids, N, P, K, Fe, Zn and Mn. AbdelWahid et al. (2006) observed that using yeast 
twice at $4 \mathrm{~g} / 1+6 \mathrm{~g} \mathrm{NPK} /$ plant significantly increased height, fresh and dry weights of shoots and N\% in roots of Euonymus japonicus plant, while yeast alone led to an increment in number of branches, stem diameter, root length, fresh and dry weights of roots, carotenoids content in the leaves and $\mathrm{K} \%$ in the roots. On the same line, were those results of Desouky (2004) on Strelitzia reginae, Broschat (2006) and El-Sayed et al. (2010 a) on Spathiphyllum and El-Sayed et al. (2010 b) on Vinca rosea cv. Major.

However, $\mathrm{GA}_{3}$ at $200 \mathrm{ppm}$ increased $\mathrm{P} \%$ and $400 \mathrm{ppm}$ caused the highest $\mathrm{K} \%$. The greatest amount of chlorophyll a was determined in the leaves of plants treated with $\mathrm{GA}_{3}$ at $400 \mathrm{ppm}$, while the plants which received 100 ppm of both $\mathrm{PP}-333$ and $\mathrm{GA}_{3}$ had the greatest percentage of total carbohydrates. In addition, El-Salami and Makary (1997) noticed that treatment of Cupressus sempervirens seedlings with $\mathrm{GA}_{3}$ at the concentration of $200 \mathrm{ppm}$ increased plant height, number of branches and fresh and dry weights of aerial parts and roots. Likely, Abdel-Wahid (1999) concluded that $\mathrm{GA}_{3}$ at the rate of $500 \mathrm{ppm}$ increased plant height and branch number of Ficus benjamina plant. Auda et al. (2002) elucidated that soaking tuberose bulbs before planting in $200 \mathrm{ppm}$ of $\mathrm{GA}_{3}$ resulted the best vegetative growth and flowering parameters. On the same line, were those results of
Saadawy et al. (2003) on Rosa hybrida cv. Mercedes, Gomaa (2003) on Dahlia pinnata, Eliwa (2003) on Cupressus macrocarpa and Agina et al. (2005) on Bougainvillea glabra, Cordyline terminailis, Ficus microcarpa Hawaii and Jasminum sambac.

However, the current work aims to detect the beneficial effect of NPK at $2 \mathrm{~g} /$ pot and $\mathrm{GA}_{3}$ application, as well as, their interaction on growth and chemical constituents of Cycas revoluta plant.

\section{MATERIALS AND METHODS}

A series of pot experiments was carried out under open field at the nursery of Hort. Res. Inst., Giza, ARC, Egypt during the two successive seasons of 2014 and 2015 to study the response of Cycas plants to treatments with NPK and different levels of $\mathrm{GA}_{3}$ and their interaction, to determine the most effective treatment for healthy growth and high quality

One-year-old plants of Cycas $(8-10 \mathrm{~cm}$ long with 3-5 leaves) were cultured on March, $1^{\text {st }}$ in both seasons in 20-cm-diameter plastic pots filled with about $2.5 \mathrm{~kg}$ of a mixture of washed sand, and compost $25 \%$ $(3: 1, \quad \mathrm{v} / \mathrm{v})$. The physical and chemical analysis of the used sand is shown in Table (1), but properties of the used compost are shown in Table (2). After one month, the plants received the following treatments:

Table 1. The physical and chemical analysis of sand during 2013 and 2014 seasons.

\begin{tabular}{|c|c|c|c|c|c|c|c|c|c|c|c|c|c|c|c|}
\hline \multirow{2}{*}{$\begin{array}{l}\text { Soil } \\
\text { texture }\end{array}$} & \multirow[b]{2}{*}{ easons } & \multicolumn{4}{|c|}{ Particle size distribution (\%) } & \multirow[b]{2}{*}{ S.P. } & \multirow{2}{*}{$\begin{array}{c}\text { E.C. } \\
(\mathrm{dS} / \mathrm{m})\end{array}$} & \multirow[b]{2}{*}{ pH } & \multicolumn{4}{|c|}{ Cations (meq/l) } & \multicolumn{3}{|c|}{ Anions (meq/l) } \\
\hline & & & & & & & & & & & & $\mathbf{K}^{+}$ & & $\mathrm{Cl}^{-}$ & 4 \\
\hline \multirow[b]{2}{*}{ (II) } & & & & & & & & 92 & & & & & 3.20 & 22.00 & \\
\hline & 2015 & 0.10 & 1.78 & 0.50 & 7.45 & 22.86 & 3.74 & 7.80 & 19.42 & 8.33 & 7.20 & 0.75 & 1.60 & 7.00 & 27.10 \\
\hline
\end{tabular}

Table 2. The physical and chemical analysis of the used compost.

\begin{tabular}{llll}
\hline Weight of dry $\left(\mathbf{m}^{\mathbf{3}}\right)$ & $590 \mathrm{~kg} / \mathrm{m}^{3}$ & Organic matter & $58 \%$ \\
Weight of wet $\left(\mathbf{m}^{\mathbf{3}}\right)$ & $730 \mathrm{~kg} / \mathrm{m}^{3}$ & $\mathbf{P}$ & $0.60 \%$ \\
Humidity & $24 \%$ & $\mathbf{K}$ & $0.79 \%$ \\
pH & 6.6 & $\mathbf{F e}$ & $630 \mathrm{ppm}$ \\
E.C. & $1.6 \mathrm{ds} / \mathrm{m}$ & $\mathbf{M n}$ & $157 \mathrm{ppm}$ \\
Total Nitrogen & $1.4 \%$ & $\mathbf{C u}$ & $30 \mathrm{ppm}$ \\
Amonium nitrogen & $5.5 \mathrm{ppm}$ & $\mathbf{Z n}$ & $40 \mathrm{ppm}$ \\
Nitrate nitrogen & $315 \mathrm{ppm}$ & & \\
\hline
\end{tabular}


1- No treatment, referred to as control.

2- NPK $(2: 1: 1)$ at $2 \mathrm{~g} /$ pot. Ammonium sulphate $\quad(20.5 \% \quad \mathrm{~N}), \quad$ calcium superphosphate $\left(15.5 \% \quad \mathrm{P}_{2} \mathrm{O}_{5}\right)$ and potassium sulphate $\left(48.5 \% \quad \mathrm{~K}_{2} \mathrm{O}\right)$ fertilizers were used to obtain the required ratio.

3- Gibberellic acid in the form of berelex tablets manufactured by ICI Co., England, as each tablet contains $1 \mathrm{~g}$ of gibberellin $\left(92 \% \mathrm{GA}_{3}\right)$, and was sprayed on the foliage six times with four weeks interval to run-off at the concentrations of 500 and $1000 \mathrm{ppm}$. Moreover, each level of $\mathrm{GA}_{3}$ was combined with the dose of NPK at 2 $\mathrm{g} /$ pot form two combined treatment.

The layout of the experiment in the two seasons was a complete randomized design (Mead et al.,1993) with three replicates, as each replicate consisted of five plants. All plants under various treatments received the usual agricultural practices recommended for such plantation whenever required.

Data were taken at the end of each season (September, 30 ${ }^{\text {th }}$ ) as follows: Plant height $(\mathrm{cm})$, number of the leaves/plant, stem diameter $(\mathrm{cm})$, number of roots, root length $(\mathrm{cm})$, as well as, fresh and dry weights of leaves, stems and roots $(\mathrm{g})$. However, in fresh leaf samples taken from the middle part of the plants, photosynthetic pigments (chlorophyll a, b and carotenoids, $\mathrm{mg} / \mathrm{g} \mathrm{f.w.)}$ were determined according to Moran (1982). However, in dry samples, the content of total carbohydrates (Herbert et al., 1971), nitrogen using micro-Kjeldahle method (Jackson, 1973), phosphorus colorimetrically as recommended by Cottenie et al. (1982) and potassium using flame-photometer (Jackson, 1973), all of them as percentage were measured. Total indoles and total phenols (mg/100 g f.w.) were measured according to the method of Saric et al. (1967), A.O.A.C. (1990) and William et al. (1965).

Data were then tabulated and statistically analyzed according to SAS program (1994) using Duncan's Multiple Range Test
(Duncan, 1955) to compare among means of the different treatments.

\section{RESULTS AND DISCUSSION}

Effect of NPK and gibberellic acid on vegetative and root growth and chemical composition of Cycas plant on:

\section{Vegetative and root growth:}

It is obvious from data in Tables ( 3 and 4) that all fertilization treatments employed in this work caused a marked increment in plant height $(\mathrm{cm})$, stem diameter $(\mathrm{cm})$, number of leaves/plant and fresh and dry weights of leaves, stem and roots $(\mathrm{g})$ with various significant differences in comparison to control treatment in the two seasons, especially the combined treatment between 2 $\mathrm{g} /$ pot NPK and gibberellic acid at $1000 \mathrm{ppm}$ which recorded the utmost high means in both seasons. However, the superiority in the two seasons was due to the interaction treatment between fertilization with $2 \mathrm{~g} / \mathrm{pot}$ $\mathrm{NPK}$ and $\mathrm{GA}_{3}$ at $1000 \mathrm{ppm}$. These results are in harmony with those detected by Wazir et al. (2004), Cardoso and Rameriz (2006), El-Sayed and El-Shal (2008) and AbdelFattah et al. (2008) on Schefflera, AbdelWahed et al. (2006) on Euonymus japonicus and El-Sayed et al. (2010 a) on Spathiphyllum.

\section{Chemical composition:}

As shown in Tables (5 and 6), it is clear that the content of chlorophyll a, b, carotenoids (mg/g f.w.), total indoles as well as the percentages of $\mathrm{N}, \mathrm{P}, \mathrm{K}$ and total carbohydrates in the leaves were markedly increased as a result of treating with either fertilization treatments used in such trial. Combining treatment between NPK (at $2 \mathrm{~g} / \mathrm{l}$ ) and $\mathrm{GA}_{3}$ at $1000 \mathrm{ppm}$ registered the highest values at all, except for total phenols. This may indicate the synergistic effect of both NPK and $\mathrm{GA}_{3}$ to lump their benefits for supplying the plants luxuriously with some nutrients and vital components that accelerate biosynthesis rate and lead finally to accumulation of more constituents in plant organs. On the same line, were those results 
Boshra A. El-Sayed et al.

Table 3. Effect of NPK and $\mathrm{GA}_{3}$ on some vegetative and root growth traits of Cycas revoluta Thunb. plants during 2014 and 2015 seasons.

\begin{tabular}{|c|c|c|c|c|c|}
\hline Treatments & $\begin{array}{l}\text { Plant height } \\
(\mathrm{cm})\end{array}$ & $\begin{array}{l}\text { Stem diameter } \\
(\mathrm{cm})\end{array}$ & $\begin{array}{c}\text { No. leaves/ } \\
\text { plant }\end{array}$ & $\begin{array}{l}\text { Root length } \\
\text { (cm) }\end{array}$ & $\begin{array}{l}\text { No. roots } \\
\text { plant }\end{array}$ \\
\hline & \multicolumn{5}{|c|}{ First season: 2014} \\
\hline Control & $15.57 \mathrm{c}$ & $1.43 \mathrm{c}$ & $2.67 \mathrm{~b}$ & $25.67 \mathrm{c}$ & $1.33 \mathrm{~d}$ \\
\hline NPK 2 g/pot & $19.50 \mathrm{bc}$ & $1.87 \mathrm{~b}$ & $3.00 \mathrm{~b}$ & $29.67 \mathrm{~b}$ & $2.00 \mathrm{~d}$ \\
\hline $\mathrm{GA}_{3}$ at 500 ppm (A) & $17.00 \mathrm{c}$ & $1.90 \mathrm{~b}$ & $3.33 \mathrm{ab}$ & $30.50 \mathrm{~b}$ & $2.33 \mathrm{~cd}$ \\
\hline $\mathrm{GA}_{3}$ at $1000 \mathrm{ppm}(\mathrm{B})$ & $21.83 \mathrm{ab}$ & $2.23 \mathrm{~b}$ & $3.33 \mathrm{ab}$ & $30.50 \mathrm{~b}$ & $3.67 \mathrm{bc}$ \\
\hline NPK 2 g/pot + A & $23.33 \mathrm{ab}$ & $3.00 \mathrm{a}$ & $4.00 \mathrm{a}$ & $32.00 \mathrm{~b}$ & $4.00 \mathrm{ab}$ \\
\hline \multirow[t]{2}{*}{ NPK 2 g/pot + B } & $25.63 \mathrm{a}$ & $3.30 \mathrm{a}$ & $4.00 \mathrm{a}$ & $35.50 \mathrm{a}$ & $5.33 \mathrm{a}$ \\
\hline & \multicolumn{5}{|c|}{ Second season: 2015} \\
\hline Control & $17.28 \mathrm{~d}$ & $1.56 \mathrm{c}$ & $3.00 \mathrm{~b}$ & $28.04 \mathrm{c}$ & $1.67 \mathrm{c}$ \\
\hline NPK 2 g/pot & $20.86 \mathrm{~cd}$ & $2.04 \mathrm{~b}$ & $3.33 \mathrm{~b}$ & $32.17 \mathrm{~b}$ & $2.33 \mathrm{c}$ \\
\hline $\mathrm{GA}_{3}$ at $500 \mathrm{ppm}(\mathrm{A})$ & $18.71 \mathrm{~d}$ & $2.10 \mathrm{~b}$ & $3.63 \mathrm{ab}$ & $33.75 \mathrm{~b}$ & $2.55 \mathrm{c}$ \\
\hline $\mathrm{GA}_{3}$ at $1000 \mathrm{ppm}(\mathrm{B})$ & $23.66 \mathrm{bc}$ & $2.40 \mathrm{~b}$ & $3.65 \mathrm{ab}$ & $33.23 \mathrm{~b}$ & $4.00 \mathrm{~b}$ \\
\hline NPK 2 g/pot + A & $24.94 \mathrm{ab}$ & $3.31 \mathrm{a}$ & $4.33 \mathrm{a}$ & $35.29 \mathrm{ab}$ & $4.34 \mathrm{~b}$ \\
\hline NPK 2 g/pot + B & $27.49 \mathrm{a}$ & $3.51 \mathrm{a}$ & $4.29 \mathrm{a}$ & $37.99 \mathrm{a}$ & $5.78 \mathrm{a}$ \\
\hline
\end{tabular}

* Means within a column having the same letters are not significantly different according to Duncan's Multiple Range Test at 5\% level.

Table 4. Effect of NPK and $\mathrm{GA}_{3}$ on fresh and dry weights of Cycas revoluta Thunb. plants during 2014 and 2015 seasons.

\begin{tabular}{|c|c|c|c|c|c|c|}
\hline \multirow{2}{*}{ Treatments } & \multicolumn{3}{|c|}{ Fresh weight (g) } & \multicolumn{3}{|c|}{ Dry weight (g) } \\
\hline & Leaves & Stem & Roots & Leaves & Stem & Roots \\
\hline & \multicolumn{6}{|c|}{ First season: 2014} \\
\hline Control & $21.32 \mathrm{e}$ & $25.21 \mathrm{~d}$ & $22.32 \mathrm{~d}$ & $9.70 \mathrm{~d}$ & $11.39 \mathrm{~d}$ & $11.12 \mathrm{~d}$ \\
\hline NPK 2 g/pot & $23.00 \mathrm{~d}$ & $26.00 \mathrm{~cd}$ & $24.20 \mathrm{c}$ & $9.99 \mathrm{~d}$ & $12.25 \mathrm{~d}$ & $11.79 \mathrm{~d}$ \\
\hline $\mathrm{GA}_{3}$ at 500 ppm (A) & $25.21 \mathrm{c}$ & $26.99 \mathrm{c}$ & $25.32 \mathrm{c}$ & $10.05 \mathrm{~d}$ & $14.00 \mathrm{c}$ & $12.00 \mathrm{~d}$ \\
\hline $\mathrm{GA}_{3}$ at $1000 \mathrm{ppm}(\mathrm{B})$ & $29.00 \mathrm{~b}$ & $30.21 \mathrm{~b}$ & $29.70 \mathrm{~b}$ & $11.22 \mathrm{c}$ & $14.99 \mathrm{c}$ & $13.99 \mathrm{c}$ \\
\hline NPK 2 g/pot + A & $30.10 \mathrm{ab}$ & $32.25 \mathrm{a}$ & $31.00 \mathrm{~b}$ & $13.00 \mathrm{~b}$ & $17.00 \mathrm{~b}$ & $14.90 \mathrm{~b}$ \\
\hline \multirow[t]{2}{*}{ NPK 2 g/pot + B } & $31.50 \mathrm{a}$ & $33.00 \mathrm{a}$ & $32.99 \mathrm{a}$ & $14.22 \mathrm{a}$ & $18.99 \mathrm{a}$ & $15.99 \mathrm{a}$ \\
\hline & \multicolumn{6}{|c|}{ Second season: 2015} \\
\hline Control & $23.75 \mathrm{c}$ & $27.35 \mathrm{~d}$ & $23.83 \mathrm{~d}$ & $10.51 \mathrm{e}$ & $12.46 \mathrm{~d}$ & $12.16 \mathrm{c}$ \\
\hline NPK 2 g/pot & $25.30 \mathrm{bc}$ & $28.39 \mathrm{~cd}$ & $26.69 \mathrm{~cd}$ & $10.90 \mathrm{de}$ & $13.49 \mathrm{~d}$ & $12.88 \mathrm{c}$ \\
\hline $\mathrm{GA}_{3}$ at 500 ppm (A) & $26.83 \mathrm{~b}$ & $29.64 \mathrm{c}$ & $27.40 \mathrm{c}$ & $11.02 \mathrm{~d}$ & $15.24 \mathrm{c}$ & $13.13 \mathrm{c}$ \\
\hline $\mathrm{GA}_{3}$ at $1000 \mathrm{ppm}(\mathrm{B})$ & $31.63 \mathrm{a}$ & $33.85 \mathrm{~b}$ & $32.63 \mathrm{~b}$ & $12.27 \mathrm{c}$ & $16.22 \mathrm{c}$ & $15.18 \mathrm{~b}$ \\
\hline NPK 2 g/pot + A & $32.48 \mathrm{a}$ & $35.25 \mathrm{ab}$ & $33.87 \mathrm{ab}$ & $14.06 \mathrm{~b}$ & $18.77 \mathrm{~b}$ & $16.57 \mathrm{ab}$ \\
\hline NPK 2 g/pot + B & $34.38 \mathrm{a}$ & $36.78 \mathrm{a}$ & $36.37 \mathrm{a}$ & $15.03 \mathrm{a}$ & $20.64 \mathrm{a}$ & $17.24 \mathrm{a}$ \\
\hline
\end{tabular}

* Means within a column having the same letters are not significantly different according to Duncan's Multiple Range Test at 5\% level. 
Table 5. Effect of NPK and $\mathrm{GA}_{3}$ on some chemical constituents of Cycas revoluta Thunb. leaves during 2014 and 2015 seasons.

\begin{tabular}{|c|c|c|c|c|c|}
\hline \multirow{2}{*}{ Treatments } & \multicolumn{3}{|c|}{ Photosynthetic pigments (mg/g f.w.) } & \multirow{2}{*}{$\begin{array}{l}\text { Total indoles } \\
\text { (mg/100 g f.w.) }\end{array}$} & \multirow{2}{*}{$\begin{array}{l}\text { Total phenols } \\
\text { (mg/100 g f.w.) }\end{array}$} \\
\hline & Chl. a & Chl. b & Carotenoids & & \\
\hline & \multicolumn{5}{|c|}{ First season: 2014} \\
\hline Control & $0.302 \mathrm{f}$ & $0.133 \mathrm{e}$ & $0.200 \mathrm{f}$ & $0.470 \mathrm{e}$ & $0.052 \mathrm{a}$ \\
\hline NPK 2 g/pot & $0.621 \mathrm{c}$ & $0.261 \mathrm{c}$ & $0.342 \mathrm{c}$ & $0.447 \mathrm{f}$ & $0.049 \mathrm{~b}$ \\
\hline $\mathrm{GA}_{3}$ at $500 \mathrm{ppm}(\mathrm{A})$ & $0.401 \mathrm{e}$ & $0.192 \mathrm{~d}$ & $0.300 \mathrm{e}$ & $0.497 \mathrm{~d}$ & $0.051 \mathrm{ab}$ \\
\hline $\mathrm{GA}_{3}$ at 1000 ppm (B) & $0.521 \mathrm{~d}$ & $0.200 \mathrm{~d}$ & $0.321 \mathrm{~d}$ & $0.540 \mathrm{c}$ & $0.042 \mathrm{c}$ \\
\hline NPK 2 g/pot + A & $0.732 \mathrm{~b}$ & $0.299 \mathrm{~b}$ & $0.491 \mathrm{~b}$ & $0.597 \mathrm{~b}$ & $0.019 \mathrm{~d}$ \\
\hline \multirow[t]{2}{*}{ NPK 2 g/pot + B } & $1.000 \mathrm{a}$ & $0.442 \mathrm{a}$ & $0.600 \mathrm{a}$ & $0.677 \mathrm{a}$ & $0.011 \mathrm{e}$ \\
\hline & \multicolumn{5}{|c|}{ Second season: 2015} \\
\hline Control & $0.401 \mathrm{e}$ & $0.127 \mathrm{e}$ & $0.200 \mathrm{e}$ & $0.513 \mathrm{de}$ & $0.057 \mathrm{a}$ \\
\hline NPK 2 g/pot & $0.812 \mathrm{c}$ & $0.253 \mathrm{~b}$ & $0.499 \mathrm{~b}$ & $0.487 \mathrm{e}$ & $0.053 \mathrm{~b}$ \\
\hline $\mathrm{GA}_{3}$ at 500 ppm (A) & $0.599 \mathrm{~d}$ & $0.132 \mathrm{de}$ & $0.390 \mathrm{~d}$ & $0.533 \mathrm{~d}$ & $0.056 \mathrm{ab}$ \\
\hline $\mathrm{GA}_{3}$ at $1000 \mathrm{ppm}(\mathrm{B})$ & $0.612 \mathrm{~d}$ & $0.149 \mathrm{~d}$ & $0.388 \mathrm{~d}$ & $0.580 \mathrm{c}$ & $0.046 \mathrm{c}$ \\
\hline NPK 2 g/pot + A & $0.991 \mathrm{~b}$ & $0.225 \mathrm{c}$ & $0.452 \mathrm{c}$ & $0.643 \mathrm{~b}$ & $0.021 \mathrm{~d}$ \\
\hline NPK 2 g/pot + B & $1.421 \mathrm{a}$ & $0.473 \mathrm{a}$ & $0.527 \mathrm{a}$ & $0.760 \mathrm{a}$ & $0.012 \mathrm{e}$ \\
\hline
\end{tabular}

* Means within a column having the same letters are not significantly different according to Duncan's Multiple Range Test at 5\% level.

Table 6. Effect of NPK and $\mathrm{GA}_{3}$ on $\mathrm{N}, \mathrm{P}, \mathrm{K}$ and total carbohydrates of Cycas revoluta Thunb. leaves during 2014 and 2015 seasons.

\begin{tabular}{|c|c|c|c|c|}
\hline Treatments & $\mathbf{N}(\%)$ & $\mathbf{P}(\%)$ & $\mathbf{K}(\%)$ & $\begin{array}{c}\text { Total } \\
\text { carbohydrates }(\%)\end{array}$ \\
\hline & \multicolumn{4}{|c|}{ First season: 2014} \\
\hline Control & $1.827 \mathrm{f}$ & $0.102 \mathrm{~d}$ & $0.800 \mathrm{e}$ & $16.34 \mathrm{~d}$ \\
\hline NPK 2 g/pot & $1.998 \mathrm{e}$ & $0.110 \mathrm{~d}$ & $0.892 \mathrm{~d}$ & $17.01 \mathrm{c}$ \\
\hline $\mathrm{GA}_{3}$ at $500 \mathrm{ppm}(\mathrm{A})$ & $2.132 \mathrm{~d}$ & $0.132 \mathrm{~d}$ & $0.999 \mathrm{c}$ & $17.09 \mathrm{c}$ \\
\hline $\mathrm{GA}_{3}$ at 1000 ppm (B) & $2.194 \mathrm{c}$ & $0.198 \mathrm{c}$ & $1.127 \mathrm{~b}$ & $18.21 \mathrm{~b}$ \\
\hline NPK 2 g/pot + A & $2.423 \mathrm{~b}$ & $0.231 \mathrm{~b}$ & $1.147 \mathrm{~b}$ & $18.99 \mathrm{a}$ \\
\hline \multirow[t]{2}{*}{ NPK 2 g/pot + B } & $2.632 \mathrm{a}$ & $0.319 \mathrm{a}$ & $1.432 \mathrm{a}$ & $19.21 \mathrm{a}$ \\
\hline & \multicolumn{4}{|c|}{ Second season: 2015} \\
\hline Control & $1.713 \mathrm{f}$ & $0.109 \mathrm{e}$ & $0.803 \mathrm{f}$ & $15.49 \mathrm{f}$ \\
\hline NPK 2 g/pot & $1.799 \mathrm{e}$ & $0.110 \mathrm{e}$ & $0.873 \mathrm{e}$ & $16.00 \mathrm{e}$ \\
\hline $\mathrm{GA}_{3}$ at 500 ppm (A) & $2.101 \mathrm{~d}$ & $0.142 \mathrm{~d}$ & $0.998 \mathrm{~d}$ & $16.45 \mathrm{~d}$ \\
\hline $\mathrm{GA}_{3}$ at 1000 ppm (B) & $2.199 \mathrm{c}$ & $0.163 \mathrm{c}$ & $1.132 \mathrm{c}$ & $17.21 \mathrm{c}$ \\
\hline NPK 2 g/pot + A & $2.352 \mathrm{~b}$ & $0.199 \mathrm{~b}$ & $1.152 \mathrm{~b}$ & $17.99 \mathrm{~b}$ \\
\hline NPK 2 g/pot + B & $2.532 \mathrm{a}$ & $0.299 \mathrm{a}$ & $1.321 \mathrm{a}$ & $18.99 \mathrm{a}$ \\
\hline
\end{tabular}


of Abdel-Fattah et al. (2008) on Brassaia actinophylla, El-Sayed et al. (2009) on Nephrolepis exaltata and El-Sayed et al. (2010 b) on Vinca rosea cv. Major.

Briefly, to obtain the best growth and highest quality from commercial point of view, it is recommended to fertilize Cycas plants with NPK (2 g/pot as a soil drench) + $\mathrm{GA}_{3}$ at $1000 \mathrm{ppm}$ as foliar spray six times with one month interval during growing season.

\section{REFERENCES}

Abdel-Fattah, Gehan H.; Abdel-Moniem, Azza M. and El-Shamy, M.A.I. (2009). Response of Australian umbrella tree (Brassaia) transplants to some fertilization, salicylic acid and dry yeast treatments. Ann. Agric. Sci., Moshtohor, 47(2):275-283.

Abdel-Fattah, Gehan H.; Rezk-Alla, B.B. and El-Fouly, Amal S. (2008). Effect of some organic additives to sand on growth and chemical composition of Brassaia actinophylla Endl. plant.Ann. Agric. Sci., Moshtohor, 46(4):477-482.

Abdel-Wahed, Safwat M.K.; Eliwa, Naglaa Y.L. and Rezk-Alla, B.B. (2006). Effect of active dry yeast and chemical fertilization on vegetative growth and the main constituents of Euonymus japonicum Thunb. plant. Fayoum J. Agric. Res. \& Dev., 20(1):136-147.

Abdel-Wahid, S.M. (1999). Physiological Studies on Ficus benjamina L. Plant. Ph.D. Thesis, Fac. Agric., Cairo Univ., Egypt.

Agina, Effat A.M.; Shalaby, H.S.; ElKhayat, A.S. and Korkar, H.M. (2005). Effect of foliar fertilization and some growth regulators on growth and chemical composition of some ornamental plants. Proc. $6^{\text {th }}$ Arab. Conf. Hort., March 20-22, Dept. Hort., Fac. Agric., Ismailia, Egypt.

A.O.A.C. (1990). Association of Official Agricultural Chemists "Official Methods of Analysis of the Association of Official
Agricultural Chemists". $15^{\text {th }}$ Ed., Arlington, Virginia 22201:877-878.

Auda, M.S.; El-Shakhs, M.H. and Shahin, S.M. (2002). Response of Polianthes tuberosa L. to different moisture and gibberellic acid levels. Egypt. J. Appl. Sci., 17(7):708-727.

Bailey, L.H. (1950). The Standard Cyclopedia of Horticulture, Vol. I (A-E). The Macmillan Company, New York, U.S.A., 1200 pp.

Broschat, T.K. (2006). Effect of phosphorus and phosphoric acid on growth and phosphorus concentration in container grown tropical ornamental plants. HortTech., 16(1):105-108.

Cardoso, V.L. and Ramirez, C.E. (2006). Tannery wastes and sewage sludge biodegradation by composting and vermicomposting process. Ingenieria Hidraulica en Mexico, 21(2):93-103.

Cottenie, A.; Verloo, M.; Kiekan, L.; Velghe, G. and Comerlynck, R. (1982). Chemical Analysis of Plants and Soils. Laboratory of Analytical and Agrochemistry. State Univ., GhentBelgium, p: 44-45.

Desouky, M.T. (2004). Improving the efficiency of different NPK fertilizer levels for Strelitzia reginae, Ait plant by using active dry yeast. Ann. Agric. Sci., Moshtohor, 42(1):239-250.

Duncan, D.B. (1955). Multiple range and multiple F-tests. J. Biometrics, 11:1-42.

Eliwa, Naglaa Y.L. (2003). Effect of gibberellic acid and chemical fertilization on growth and chemical composition on Cupressus macrocarpa seedlings. Proc. the First Egyptian-Syrian Conference for Agriculture and Food in The Arab World. Minia Univ., Egypt $8-11^{\text {th }}$ December 2003.

El-Salamy, I.H. and Makary, B.S. (1997). Response of Cupressus sempervirens L. seedlings to gibberellic acid and foliar 
nutrition. Assuit J. Agric. Sci., 28(1):2135.

El-Sayed, Boshra A. and El-Shal, S.A. (2008). Effect of growing media and humic acid on Schefflera quality. J. Agric. Sci., Mansoura Univ., 33(1):371381.

El-Sayed, Boshra A.; Abdel-Moniem, Azza M. and Shahin, S.M. (2010 a). Improving efficiency of NPK fertilizer for Spathiphyllum plant by active dry yeast at various levels. J. Biol. Chem. \& Environ. Sci., 5(4):1-12.

El-Sayed, Boshra A.; Ahmed, Samira S. and Shahin, S.M. $(2010$ b). Response of Vinca rosea $\mathrm{cv}$. Major plant to chemical and biofertilization treatments. J. Biol. Chem. \& Environ. Sci., 5(4):25-38.

El-Sayed, Boshra A.; El-Din, Hanan A. and Shahin, S.M. (2009). Response of Nephrolepis exaltata Schatt. plant to medium type and nitrobien biofertilization. J. Biol. Chem. \& Environ. Sci., 4(1):705-717.

Gomaa, A.O. (2003). Effect of foliar spraying with gibberellic acid and calcium on growth and flowering of Dahlia pinnata plants. Egypt. J. Agric. Res., NRC, 1(3): 585-605.

Herbert, D.; Philips, P.J. and Strange, R.E. (1971). Determination of total carbohydrates. Methods in Microbiology, 5(8):290-344.

Jackson, M.L. (1973). Soil Chemical Analysis. Prentice-Hall of India Private Limited M-97, New Delhi, India, 498 pp.
Mead, R.; Curnow, R.N. and Harted, A.M. (1993). Statistical Methods in Agriculture and Experimental Biology, $2^{\text {nd }}$ Ed., Chapman \& Hall Ltd., London, 335 pp.

Moran, R. (1982). Formula for determination of pigments extracted with $\mathrm{N}, \mathrm{N}$ dimethyl formamide. Plant Physiol., 69:1376-1381.

Saadawy, F.M.; Abo-Taleb, N. and Gomaa, S.A.A (2003). Effect of pruning and growth regulators on rose growth and flowering. II. Gibberellic acid application. J. Agric. Res., Tanta Univ., 29(2): 515-537.

Saric, M.; Kastrori, R.; Curic, R.; Cupina T. and Geric, I. (1967). Chlorophyll Determination. Univ U Noven Sadu Praktikum is Fiziologize Biljaka, Beogard, Haucna, Anjiga, 215 pp.

SAS Program (1994). SAS/STAT User's Guide Statistics. Vers. 6.04, $4^{\text {th }}$ Ed., SAS Institute Inc., Cary; N.C., USA.

Wazir, M.G.; Amin, N.; Khan, I. and Khan, I.M. (2004). Effect of different potting mixtures and nitrogen sources on the performance of Brassaia seedlings. Sarhad J. Agric., 20(1):25-31.

William, M.; Chichlilo, P.; Clifford, P.A. and Reynolds, M. (1965). Official Methods of Analysis of the Association of Official Agriculture Chemists, $10^{\text {th }}$ Ed., Washington D.C. 20044:52-55.

\section{تأثير NPK وحمض الجبريليك على نمو وجودة نبات السيكاس (Cycas revoluta "Thunb.")}

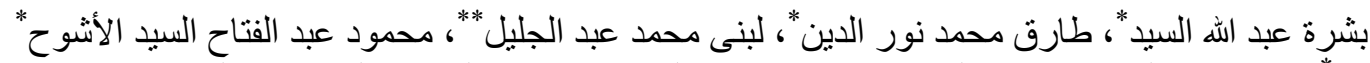

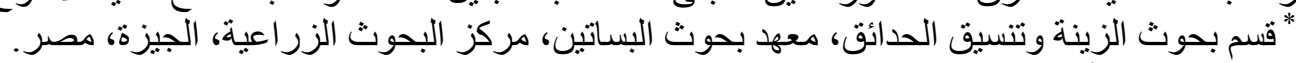

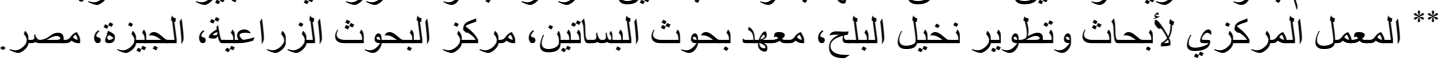

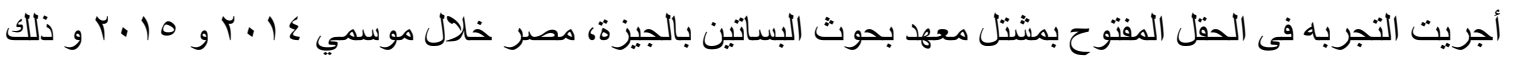

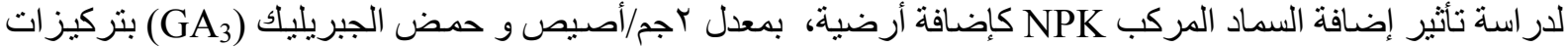

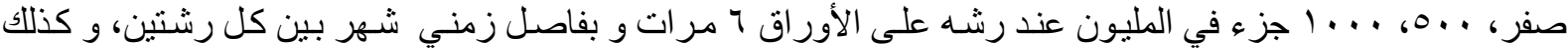




\section{Boshra A. El-Sayed et al.}

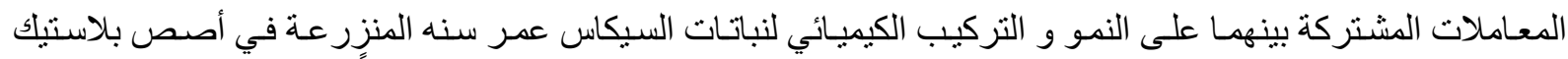

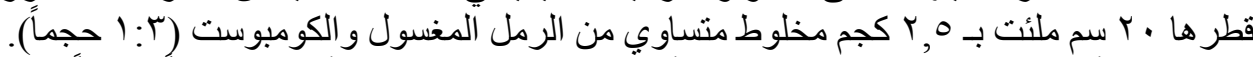

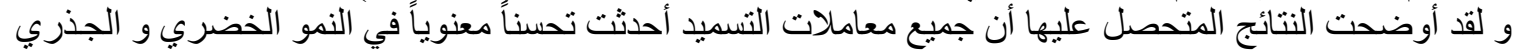

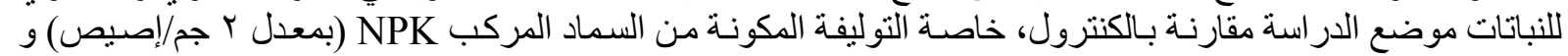

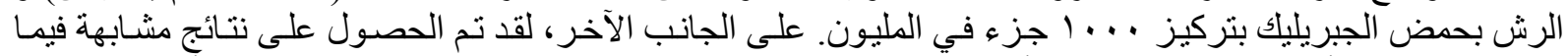

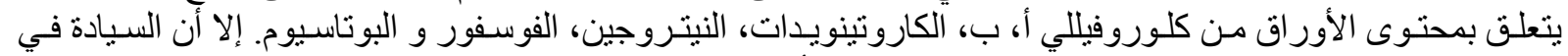

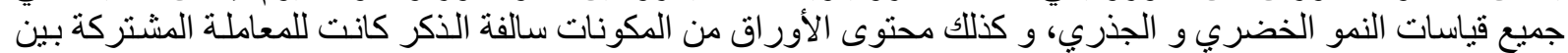

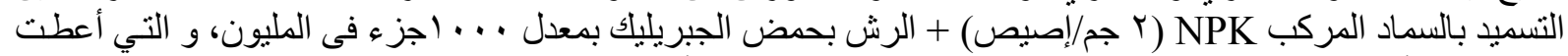

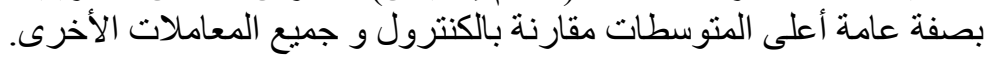

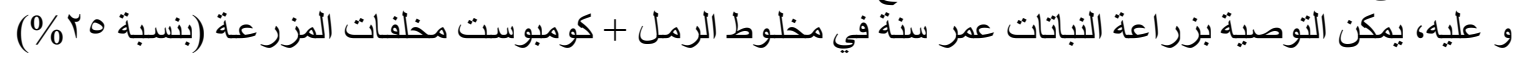

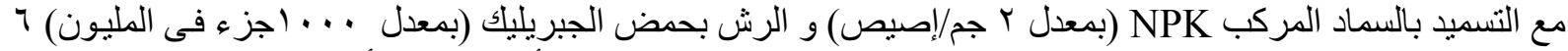
مر ات و بفاصل شهر بين كل رشتين متتاليتين خلال موسم النشاط للحصول على الفي أفضل نمو و أعلى جودة. 